\title{
Inflorescence Removal Affects Root Yield of American Ginseng
}

\author{
John T.A. Proctor, David C. Percival, and Dean Louttit \\ Department of Horticultural Science, University of Guelph, Guelph, Ont. \\ N1G 2W1, Canada
}

Additional index words. Panax quinquefolium, root size distribution, plant density

\begin{abstract}
Manual removal of inflorescences from mature (3- and 4-year-old) American ginseng plants (Panax quinquefolium L.) at commercial timing (early July, $\approx 25 \%$ flowers open) increased root yield at harvest. Consecutive inflorescence removal for 2 years (third and fourth) increased yield 55.6\%. Inflorescence removal in 4-year-old plants increased yield by $34.7 \%$ compared with $26.1 \%$ in 3-year-old plants. Analysis showed that the largest portion of roots $(\approx 40 \%)$ was in the medium category $(10-20 \mathrm{~g})$, and inflorescence removal did not influence root size distribution. Root yield for 3-year-old plants increased quadratically with plant density, with plants lacking inflorescences having an estimated yield increase of $25 \%$. Maximum yields of $2.4 \mathrm{~kg} \cdot \mathrm{m}^{-2}$ for deflowered plants were achieved at a plant density of $170 \mathrm{plants} / \mathrm{m}^{2}$. To maximize ginseng root yield, all plants except those needed to provide seed for future plantings should have inflorescences removed.
\end{abstract}

American ginseng is a perennial herbaceous plant grown for its fleshy root and seeds (Proctor, 1996; Proctor and Bailey, 1987). North America production is primarily in Ontario and British Columbia, Canada, and Wisconsin, United States. Once harvested and dried, the root is sold to brokers and exported, primarily to Hong Kong. Seeds are traded by growers within and between the producing areas. There are no official Canadian government statistics for prices received for ginseng roots or seed. Calculated annual values from 1988-96 are based on several sources (Table $1)$. Due to variability in root and seed returns (Table 1), growers are unsure whether to grow plants for seed, root, or both. For instance, in 1995, growers removed inflorescences in June and July but excessive heat from early July to mid-August resulted in poor fruit set and seed development (McElhone, 1995). This shortage of "green" unstratified seed caused prices to increase from $\$ 55 / \mathrm{kg}$ in 1994 to $\$ 154 / \mathrm{kg}$ in 1995 (Table 1).

Little is known about fruit set and development in ginseng (Proctor and Bailey, 1987). In commercial practice, a small proportion of 2year-old plants may bear flowers and seed, but the seeds usually are not harvested. Seeds from 3-year-old plants can be used for establishing plantings, but those from 4-year-old plants are preferred when available. Some growers remove flowers manually from plants

Received for publication 23 Dec. 1997. Accepted for publication 10 July 1998 . This research was supported in part by J.C.K. Farms Ltd. and the Ontario Ministry of Agriculture, Food, and Rural Affairs. We are indebted to William Matthes-Sears for valuable help with the statistical analysis. We gratefully acknowledge the support of ginseng growers Mike Atkins and Jeff Rice. The cost of publishing this paper was defrayed in part by the payment of page charges. Under postal regulations, this paper therefore must be hereby marked advertisement solely to indicate this fact. in June at an estimated cost of \$2500/ha and claim higher root yields. Others allow the seed and root to develop simultaneously. In some crops, e.g., potato (Solanum tuberosum L.), flowering and fruiting depress tuber yield in some years but not others (Bartholdi, 1942; Proudfoot, 1965), or have variable effects depending on environmental conditions (Jansky and Thompson, 1990).

The three objectives were to: a) determine the effects of inflorescence removal in 1 or 2 years on root yield and size distribution; b) estimate when inflorescence removal is economically rewarding, and c) determine the relationship between inflorescence removal and plant density.

\section{Materials and Methods}

Inflorescence removal experiments were done on two commercial ginseng farms near Waterford, Ont. Plants were established at a seeding rate of $112 \mathrm{~kg} \cdot \mathrm{ha}^{-1}$ and grown using standard North American techniques and cultural methods similar to those described by Currie (1980), Proctor (1980), and Stathers and Bailey (1986). Plants were grown on raised soil beds covered with $5-10 \mathrm{~cm}$ of straw mulch. Wooden lath shades were placed $\approx 2 \mathrm{~m}$ above the beds to reduce solar radiation to an optimal $15 \%$ to $25 \%$ of full sunlight. Standard commercial practices for pest control were followed (Ontario Ministry of Agriculture, Food and Rural Affairs, 1997).

Five experiments were conducted between 1989 and 1995 (Table 2). Treatments to all plants in a $1-\mathrm{m}^{2}$ section of the raised bed were applied during early July, which coincided with timing of commercial inflorescence removal. Treatments consisted of a control (no inflorescence removal) or removal of the inflorescences, including flowers, fruit, and developing seeds. A completely randomized experimental design was used with data being collected from four $1-\mathrm{m}^{2}$ sections of a raised bed for each treatment. Expt. 1 was conducted in 1989 and 1990 and consisted of inflorescence removal in both the third and fourth year of production. Expt. 2 consisted of inflorescence removal in 3- and 4-year-old plants in 1991 and was repeated in 1992. In Expt. 3, inflorescences were removed from 3 -year-old plants on two farms to allow for comparison of farms. Expt. 4 consisted of inflorescence removal in the third year of production from years 1991-95, to determine if there was a year effect. The timing of inflorescence removal was examined in Expt. 5, with inflorescences being removed early-, mid-, or lateseason at 7-d intervals during the flowering period. Roots were hand-dug in October of each year, washed free of soil, and weighed. To compare effects of treatments on root size distribution in 1992, 1994, and 1995, roots were weighed individually and classified as small ( $<10 \mathrm{~g}$ fresh weight), medium $(10-20 \mathrm{~g})$, and large $(>20 \mathrm{~g})$. The root size distribution data were analyzed using the G-test for goodness of fit (Sokol and Rohlf, 1981). For extrapolation of root yields from $\mathrm{kg} \cdot \mathrm{m}^{-2}$ to $\mathrm{t} \cdot \mathrm{ha}^{-1}$, an estimate of two-thirds of actual cropping area was used (Konsler, 1982).

Each year at the time of treatment, all plants in the treatment area were counted to determine plant density. This was necessary because although initial seeding rates were similar, and should have given $\approx 300$ seedlings $/ \mathrm{m}^{2}$, only about one-third of these persisted to year 3 (see Fig. 1). At harvest these 3year-old fresh root yields $\left(\mathrm{kg} \cdot \mathrm{m}^{-2}\right)$ and their associated plant densities (plants $/ \mathrm{m}^{2}$ ) were used for the study of yield/plant density relationships (Fig. 1). Analysis of variance and regression analysis of the data were carried out using the General Linear models procedure of SAS (SAS Institute, 1988).

\section{Results and Discussion}

Yield. Inflorescence removal in years 3 and 4 increased cumulative root weight $55.6 \%$ (Expt. 1, Table 2). The increase was $34.7 \%$ in 4-year-old plants, but only $25.9 \%$ in 3 -yearold plants (Expt. 2, Table 2). Since most North

Table 1. Estimated farm-gate returns ${ }^{\mathrm{z}}$ (in Canadian dollars) for dry ginseng root and for freshly harvested ("green") and 12-month stratified seed from 1988 to 1996 .

\begin{tabular}{lccc}
\hline & Roots & \multicolumn{2}{c}{ Seed $(\$ / \mathrm{kg})$} \\
\cline { 3 - 4 } Year & $(\$ / \mathrm{kg})$ & "Green"y & "Stratified"y \\
\hline 1988 & 110 & 90 & 180 \\
1989 & 110 & 110 & 200 \\
1990 & 120 & 130 & 180 \\
1991 & 130 & 190 & 400 \\
1992 & 120 & 190 & 400 \\
1993 & 100 & 120 & 120 \\
1994 & 80 & 55 & 100 \\
1995 & 88 & 154 & 120 \\
1996 & 55 & 35 & 65
\end{tabular}

${ }^{2}$ Sources: Canadian Imperial Ginseng (1994); McElhone (1995); Oliver and Geldart (1994); Tai (1994); and purchases of small lots from growers. "Green" seed are those that are freshly harvested whereas "stratified" seed have been in stratification boxes for 1 year (Proctor and Louttit, 1995). 
Table 2. Effects of inflorescence removal ${ }^{z}$ on root fresh weight of American ginseng.

\begin{tabular}{|c|c|c|c|c|c|c|c|c|c|}
\hline \multirow[b]{2}{*}{ Expt. } & \multirow{2}{*}{$\begin{array}{c}\text { Year } \\
\text { (age at } \\
\text { harvest) }\end{array}$} & \multirow{2}{*}{$\begin{array}{c}\text { Year(s) or season } \\
\text { inflorescence } \\
\text { removed }\end{array}$} & \multirow{2}{*}{$\begin{array}{l}\text { Root } \\
\text { fresh } \\
\text { wt (g) }\end{array}$} & \multirow{2}{*}{$\begin{array}{l}\text { Increase } \\
\text { from } \\
\text { removal }(\%)\end{array}$} & \multicolumn{5}{|c|}{ Significance of: } \\
\hline & & & & & Removal & Age & Farm & $\mathrm{Yr}$ & Season \\
\hline \multirow[t]{2}{*}{1} & $1990(4)$ & Control & 16.9 & & & & & & \\
\hline & & $3+4$ & 26.3 & 55.6 & $*$ & & & & \\
\hline \multirow[t]{4}{*}{2} & $1991-92(3)$ & Control & 13.5 & & & & & & \\
\hline & & 3 & 17.0 & 25.9 & $*$ & & & & \\
\hline & $1991-92(4)$ & Control & 21.9 & & & & & & \\
\hline & & 4 & 29.5 & 34.7 & $*$ & $*$ & & NS & \\
\hline \multirow[t]{2}{*}{3} & 1992(3) & Control & 14.2 & & & & & & \\
\hline & & 3 & 19.0 & 33.8 & $*$ & & NS & & \\
\hline \multirow[t]{2}{*}{4} & 1991-95(3) & Control & 13.9 & & & & & & \\
\hline & & 3 & 17.5 & 25.8 & $*$ & & & NS & \\
\hline \multirow[t]{4}{*}{5} & $1995(3)$ & Control & 15.7 & & & & & & \\
\hline & & Early season & 17.8 & 13.4 & $*$ & & & & \\
\hline & & Mid season & 19.5 & 24.2 & $*$ & & & & \\
\hline & & Late season & 17.7 & 12.7 & $*$ & & & & NS \\
\hline
\end{tabular}

${ }^{\mathrm{z}}$ Inflorescence removal at commercial timing unless otherwise stated.

Ns, *Nonsignificant or significant at $P<0.05$. None of the interactions in Expts. 2, 3, and 4 were significant.

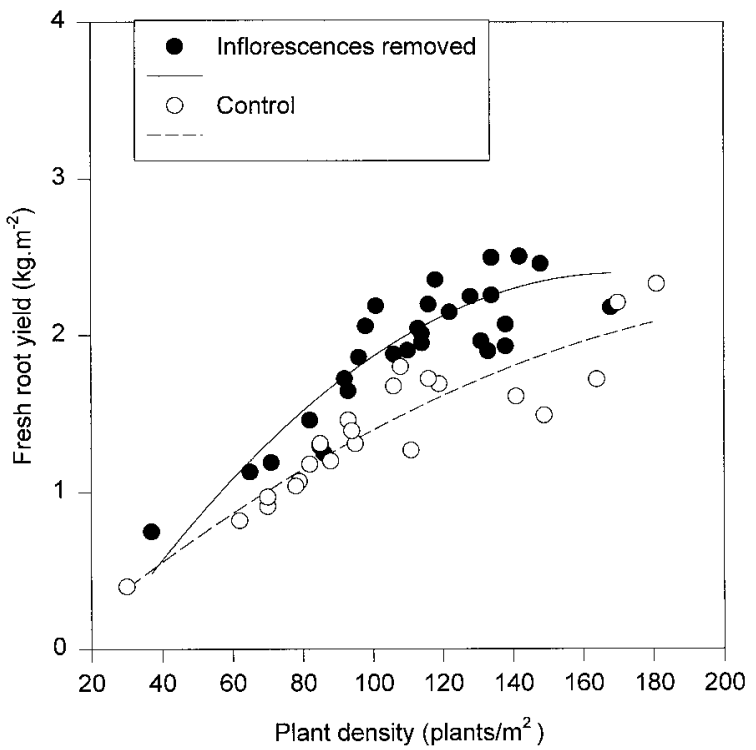

Fig. 1. Relationship between fresh root yield of 3-year-old American ginseng plants and plant density for plants with (control) and without inflorescences. Plotted lines are from regression analyses. Control: $\mathrm{y}=-0.16+0.0194 \mathrm{x}-0.000039 \mathrm{x}^{2}\left(R^{2}=0.84\right), \mathrm{n}=22$. Inflorescences removed: $\mathrm{y}=-0.739+0.037 \mathrm{x}$ $-0.00011 \mathrm{x}^{2}\left(R^{2}=0.70\right), \mathrm{n}=28$.

American growers now harvest at the end of year 3 , the $26 \%$ value was used in calculations of economic returns (see below). The effects of inflorescence removal were similar on both farms, giving an average root-weight increase of $33.2 \%$ (Expt. 3, Table 2). Inflorescence removal effects were similar in each year (Expt. 4, Table 2).

The time of inflorescence removal was not an important factor (Expt. 5, Table 2), possibly due to flower development in the umbel inflorescence. Flowering and fruit set occur over a 3- to 4-week period. After the initial flowering, the inflorescence contains flowers and fruit at various stages of development. Midflowering season may be the best time for inflorescence removal as the umbel is readily visible in the canopy at this time.

Flower removal did not change root size distribution (data not shown). The largest portion of roots $(40 \%)$ was in the medium category $(10-20 \mathrm{~g})$, with $36 \%$ in the small $(<10 \mathrm{~g})$ and $24 \%$ in the large $(>20 \mathrm{~g})$ categories.
Economic return. The economic return expected from inflorescence removal should guide management decisions for ginseng growers. Economic comparisons were made when both seed and root prices were both relatively high (1991) and low (1994), as gross returns for seeds and roots fluctuated over the period of these experiments (Table 1). Only data for 3 -year-old plantings were compared.

Inflorescence removal from plants in their third year only (1991 and 1992) increased root weight $26 \%$ (Table 2). Seed yield was 112 $\mathrm{kg} \cdot \mathrm{ha}^{-1}$ and the sale price was $\$ 176 / \mathrm{kg}$. Thus, removing the inflorescence in 1991 would have resulted in a loss of $(112 \times \$ 176)+$ $\$ 2500 /$ ha removal costs $=\$ 22,212 /$ ha. Inflorescence removal increased root yield 2240 to $2822 \mathrm{~kg} \cdot \mathrm{ha}^{-1}$. With root prices at $\$ 132 / \mathrm{kg}$ (actual grower receipt), this $582-\mathrm{kg}$ increase would have yielded $\$ 76,824$. Therefore, the projected net profit with inflorescence removal was $\$ 54,612 /$ ha.

Inflorescence removal in 1994 increased root yield by $23 \%$. Seed yield was $364 \mathrm{~kg} \cdot \mathrm{ha}^{-1}$ and value was $\$ 55 / \mathrm{kg}$. The loss from inflorescence removal would have been $(364 \times \$ 55)+$ $\$ 2500 /$ ha removal costs $=\$ 22,520 /$ ha . Root yield increase was from 2240 to $2755 \mathrm{~kg}$. At $\$ 77 / \mathrm{kg}$, this $515 \mathrm{~kg}$ increase would result in a gross return of $\$ 39,655$. Therefore, net returns from inflorescence removal would have been $\$ 17,115 /$ ha.

Declining returns to growers for seed (Table 1) suggest that all inflorescences should be removed from plants to maximize root yield and quality. Only sufficient flowering plants to provide seed for planting should be retained. Three-year-old plants will produce 100$200 \mathrm{~kg} \cdot \mathrm{ha}^{-1}$ of seeds and 4-year-old plants 300-500 kg.ha-1 (Oliver, 1998).

Plant density. Generally, root yield of 3year-old plants increased quadratically with plant density (Fig. 1). Inflorescence removal further increased yield $\approx 25 \%$ over all plant densities; this value is similar to that of $26 \%$ (mean of 3-year-old increases in Table 2). Maximum root yield for plants with inflorescences removed was $2.37 \mathrm{~kg} \cdot \mathrm{m}^{-2}$ at 168 plants/ $\mathrm{m}^{2}$ (Fig. 1).

Konsler and Shelton (1984) obtained the greatest root yield $\left(3.31 \mathrm{~kg} \cdot \mathrm{m}^{-2}\right)$ without inflorescence removal at $258 \mathrm{plants} / \mathrm{m}^{2}$, the highest plant density tested, for 5-year-old ginseng. This yield did not increase in year 6 . The plants grown by Konsler and Shelton (1984) were allowed to carry flowers and fruit. However, in the present decade, North American ginseng growers are attempting to maximize root yields in the third year. Our data suggest that this can be done at a plant density (with inflorescences removed) of $\approx 170$ plants $/ \mathrm{m}^{2}$ and will yield $2.4 \mathrm{~kg} \cdot \mathrm{m}^{-2}$ or $16 \mathrm{t} \cdot \mathrm{ha}^{-1}$.

These results, collected over a number of years with different growing seasons, were consistent, unlike data for the potato, a tuber crop (Jansky and Thompson, 1990). This may reflect the strong flowering capacity of ginseng, whereas an estimated one-third of current potato cultivars do not form fruits (Ross, 1986). Also, ginseng is still essentially a wild species, the industry being based on plants taken from their native woodland habitat (Proctor and Bailey, 1987). Presumably, these plants rely on sexual reproduction for propagation and have retained this characteristic in cultivation.

\section{Literature Cited}

Bartholdi, W.L. 1942. Influence of flowering and fruiting upon vegetative growth and tuber yield in the potato. Minnesota Agr. Expt. Sta. Tech. Bul. 150.

Canadian Imperial Ginseng. 1994. Corporate information document. Vancouver, B.C., Canada.

Currie, D.J. 1980. Ginseng cultivation under artificial shade, p. 16-22. In: Proc. 2nd Natl. Ginseng Conf., Missouri Dept. of Conserv., Jefferson City.

Jansky, S.H. and D.M. Thompson. 1990. The effect of flower removal on potato tuber yield. Can. J. Plant Sci. 70:1223-1225.

Konsler, T.R. 1982. Some responses of American ginseng (Panax quinquefolium $\mathrm{L}$.) to kind of bed mulch and to plant spacing through four growing seasons, p. 14-24. In: Proc. 4th Natl. Ginseng Conf., Lexington, Ky.

Konsler, T.R. and J.E. Shelton. 1984. Plant spacing, 
mulches and soil effects on cultivated American ginseng (Panax quinquefolium L.), p. 23-49. In: Proc. 6th North Amer. Ginseng Conf., Univ. of Guelph, Ontario, Canada.

McElhone, H. 1995. Green seed prices skyrocket. Can. Tobacco Grower 44(6): 14

Oliver, A. 1998. Ginseng production guide for commercial growers. Assoc. Ginseng Growers of British Columbia (B.C.) and B.C. Min. of Agr., Fisheries and Food.

Oliver, A. and H.G. Geldart. 1994. Planning for profit: Ginseng. British Columbia Min. Agr. Fisheries and Food, Agdex-260-810.

Ontario Ministry of Agriculture, Food and Rural Affairs. 1997. 1997-98 Ginseng pest control recommendations. Publ. 610.
Proctor, J.T.A. 1980. Some aspects of the Canadian culture of ginseng (Panax quinquefolium L.), particularly the growing environment, p. 39-47. In: Proc. 3rd Intl. Ginseng Symp., Korean Ginseng Research Inst., Seoul.

Proctor, J.T.A. 1996. Ginseng: Old crop, new directions, p. 565-577. In : J. Janick (ed.). Progress in New Crops, Proc. 3rd Natl. Symp., New Crops: New opportunities, new technologies. ASHS Press, Alexandria, Va.

Proctor, J.T.A. and W.G. Bailey. 1987. Ginseng: Industry, botany and culture. Hort. Rev. 9:187-236.

Proctor, J.T.A. and D. Louttit. 1995. Stratification of American ginseng seed: embryo growth and temperature. Korean J. Ginseng Sci. 19:171174.
Proudfoot, K.G. 1965. The effects of flowering and berry formation on tuber yield in Solanum demissum Lindl. Eur. Potato J. 8:118-119.

Ross, H. 1986. Potato breeding-Problems and perspectives. Verlag Paul Parey, Berlin.

SAS Institute. 1988. SAS/STAT user's guide, release 6.03. SAS Inst., Cary, N.C.

Sokal, R.R. and F.J. Rohlf. 1981. Biometry. 2nd ed. Freeman, San Francisco.

Stathers, R.J. and W.G. Bailey. 1986. Energy receipt and partitioning in a ginseng shade canopy and mulch environment. Agr. For. Meteorol. $37: 1-14$.

Tai, J. 1994. Investment in ginseng: The root to wealth? Brink, Hudson and Lefavor, Vancouver, B.C., Canada. 